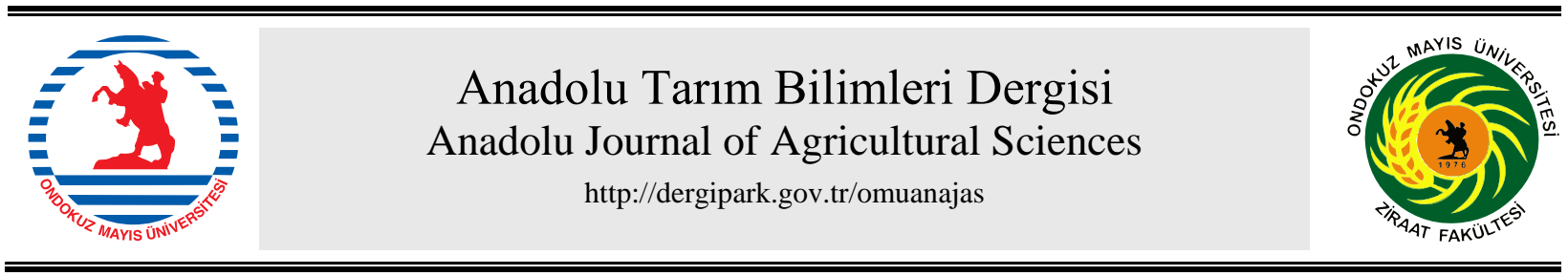

Araştırma/Research

Anadolu Tarım Bilim. Derg./Anadolu J Agr Sci, 35 (2020)

ISSN: 1308-8750 (Print) 1308-8769 (Online)

doi: 10.7161/omuanajas.715749

\title{
Assessments of the productivity and profitability of diverse crops and cropping systems as influenced by conservation agriculture practices under a semi-arid rainfed environment of western India
}

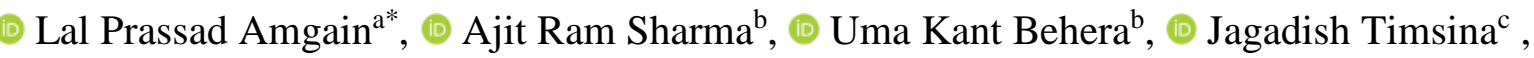 \\ Jiban Shrestha ${ }^{\mathrm{d}}$
}
${ }^{a}$ Agronomy Department, Institute of Agriculture and Animal Science, Tribhuvan University, Rampur campus, Khairahani Chitwan, Nepal
${ }^{b}$ Agronomy Division, Indian Agricultural Research Institute, Pusa, New Delhi, India
'Soils and Environment Research Group, Veterinary and Agricultural Sciences, University of Melbourne, Victoria-3010, Australia
${ }^{d}$ Agriculture Botany Division, Nepal Agriculture Research Council, Khumaltar, Lalitpur, Nepal

*Sorumlu yazar/corresponding author: lalprasad@iaas.edu.np

Geliș/Received 07/04/2020 Kabul/Accepted 22/09/2020

\begin{abstract}
Field studies were conducted under a conservation-tilled rainfed semi-arid environment in New Delhi, India, during the rainy- and winter-seasons of 2010-11 and 2011-12 to assess the effects of diverse crops and cropping systems and residue retention on system productivity and profitability of nine double-cropping systems. Pearlmillet (Pennisetum glaucum (L.) R. Br.), clusterbean (Cyamopsis tetragonoloba L.) and greengram (Vigna radiata L. Wilczek) were grown under no-residue, crop residues, and Ipil-ipil (Leucaena leucocephala) twigs during the rainy season in 2010 and 2011. Subsequently, wheat (Triticum aestivum L.), chickpea (Cicer arietinum L.), and mustard (Brassica juncea L.) were grown during winter of 2010-11 and 2011-12 after summer crops. Randomized Complete Block, Strip and Strip-plot designs with four replications were followed to analyze the data from the nine rainfed cropping systems with different residue management practices. Significantly higher $(\mathrm{p} \leq 0.05)$ pearlmillet-equivalent yield was obtained with clusterbean after wheat and chickpea under Leucaena twigs, followed by residue retention than pearlmillet or greengram. Significantly higher ( $\mathrm{p} \leq 0.05$ ) wheat-equivalent yield (4.15 t ha-1 in 2010-11, and $3.77 \mathrm{t}$ ha-1 in 2011-12) was obtained with mustard under Leucaena twigs after clusterbean. The system profitability (net returns and B: C ratio) were higher under clusterbean-mustard and clusterbean-wheat systems with Leucaena twigs. It is suggested that the clusterbean-mustard, greengram-wheat and pearlmillet-chickpea systems with Leucaena twigs were the most beneficial systems under zero-tilled rainfed conditions in the semi-arid environments of north-western India.
\end{abstract}

Keywords: Conservation tillage Productivity Rainfed crops Cropping systems Residue retention

\section{Introduction}

Globally, rainfed agriculture covers about $80 \%$ of the area and accounts for about $60 \%$ of the global foodgrain production (Amgain et al. 2019). About $67 \%$ of 143 million ha net cultivated area in India is rainfed (Saxena 2012), and the future prosperity of India depends on rainfed agriculture because about $91 \%$ of coarse grains and pulses, $80 \%$ of oilseeds, $60 \%$ of cotton, $50 \%$ of rice, and $19 \%$ of wheat are produced under rainfed conditions (Prasad and Bhatia 2009). Yields of those rainfed crops are almost half compared with those of the irrigated crops due to the limited and erratic rainfall resulting in mid-or late-season moisture stress. Cultivation of short-duration and relatively lowwater requiring crops, such as pearlmillet, clusterbean and greengram, in summer (rainy) season and/or leaving 
the land fallow during the remainder of the season, and cultivating drought-hardy winter-season crops like wheat, chickpea and mustard on the conserved soil moisture under conventional tillage is followed in the semi-arid areas of north-western India (Singh et al. 2008). The "age-old" practice of including legumes and oilseeds in the cereal-based systems utilizes the soil nutrients and residual moisture, minimizes pest hazards, and provides balanced proteins and fatty acids to human beings (Dhyani et al. 2009). In irrigated areas of northwestern India, about 20 diversified cropping systems are practiced (Gill and Ahlawat 2006), but in rainfed areas, only a few systems have been documented, of which, clusterbean-wheat and clusterbean-mustard are considered profitable. Clusterbean-mustard system was found to be more remunerative than clusterbean $\neg$-wheat at Hisar, India; however, clusterbean-wheat gave higher net returns and water-use efficiency than other rainfed systems at Gwalior (Saxena et al. 1997; Singh et al. 1998). Likewise, net returns and benefit: cost ratio were also higher than clusterbean-wheat system with greengram-wheat in Rajasthan (Singh et al. 2008). Similarly, on-farm experiments conducted under rainfed conditions at 35 different locations in five districts of Rajasthan revealed that clusterbean-wheat sequence recorded the highest gross returns, followed by clusterbean-mustard and pearlmillet-wheat crop sequences (Lal et al. 2004). There are reports of remarkable increases in crop yields in maize-wheat systems, under scanty rainfall, through the maintenance of appropriate vegetative cover in rainfed areas (Acharya et al. 1998; Sharma et al. 1998; Sharma and Acharya 2000; Sharma et al. 2010). Pruned twigs of Leuceana as mulch were found to be effective in conserving soil moisture and build the soil fertility status for both rainy and winter-season crops because of twigs' high N content and easy availability (Sharma and Behera 2009; Sharma et al. 2010; 2011); significant residual effects were observed on soil fertility and productivity of subsequent crops (Jones et al. 1996; Lehria et al. 2006).

Despite several instances of sustainable productivity and profitability of rainfed crops and cropping systems based on the principles and practices of conservation agriculture (CA) (i.e., zero or reduced tillage, residue retention, and sustainable crop rotations), adoption of CA under rainfed conditions has reportedly been rather slow (Pittelkow et al. 2014). Therefore, the present research work was undertaken to explore the feasibility of double-cropping systems through CA-based practices, such as zero-tillage (Erenstein and Laxmi 2008) and residue recycling (Singh et al. 2005) in diversified cropping systems (Gill and Ahlawat 2006) under the rainfed ecosystem in a semi-arid environment of northwest India.

\section{Material and Methods}

\subsection{Research site, soil and weather}

Field experiments were conducted on a fixed site during rainy (June-October) and winter (October-April) seasons of 2010-11 and 2011-12 at the Research Farm of the Indian Agricultural Research Institute, New Delhi (28.4o N, 77.10 E, 229 masl). The soil at the site was sandy-loam with bulk density of $1.55 \mathrm{Mg} \mathrm{m}-3$ and field capacity of $18.7 \%(w / w)$. It had $0.40 \%$ organic C, 147.2 kg ha-1 KMnO4-oxidizable N, $17.0 \mathrm{~kg}$ ha-1 $0.5 \mathrm{~N}$ NaHCO3-extractable P, 225.1 kg ha-1 1.0 N NH4OAcexchangeable $\mathrm{K}$, and a $\mathrm{pH}$ of 7.5 at the initiation of the experiment on summer season of 2010 (Table 1). The average annual rainfall of Delhi during the last 10 years was $739 \mathrm{~mm}$, of which $>80 \%$ generally occurred during the monsoon season (July-September). There was $30.6 \%$ higher rainfall in $2010-11(953.7 \mathrm{~mm})$ than in 2011-12 (662.2 mm), indicating contrasting weather conditions during the two years of experimentation (Figure 1-3). In the winter season of 2010-11, there was about $85 \mathrm{~mm}$ timely distributed rainfall, while rainfall was only $34 \mathrm{~mm}$ distributed sparsely in 2011-12.

Table 1. Physico-chemical and biological characteristics of the soil of the experimental site at the initiation of the experiment in $2010^{*}$.

\begin{tabular}{|c|c|}
\hline Soil properties & Values \\
\hline \multicolumn{2}{|l|}{ Physical properties } \\
\hline $\begin{array}{l}\text { Mechanical composition (Hydrometer method) } \\
\text { Sand (\%) }\end{array}$ & 62.9 \\
\hline $\begin{array}{l}\text { Silt }(\%) \\
\text { Clay }(\%) \\
\text { Textural class }\end{array}$ & $\begin{array}{l}12.3 \\
24.8 \\
\text { Sandy }\end{array}$ \\
\hline $\begin{array}{l}\text { Moisture content at } 1 / 3 \text { atmospheric tension (\%) } \\
\text { (Pressure plate apparatus) }\end{array}$ & 18.8 \\
\hline $\begin{array}{l}\text { Moisture content at } 15 \text { atmospheric tension (\%) } \\
\text { (Pressure plate apparatus) }\end{array}$ & 6.5 \\
\hline Bulk density (0-15 cm layer) $\left(\mathrm{Mg} \mathrm{m}^{-3}\right)$ & 1.55 \\
\hline Hydraulic conductivity $\left(\mathrm{cm} \mathrm{hr}^{-1}\right)$ & 1.31 \\
\hline Infiltration rate $\left(\mathrm{cm} \mathrm{hr}^{-1}\right)$ & 1.06 \\
\hline \multicolumn{2}{|l|}{ Chemical properties } \\
\hline Organic C (\%) (Wet digestion) & 0.40 \\
\hline Available $\mathrm{N} \mathrm{kg} \mathrm{ha-1} \mathrm{(Alkaline} \mathrm{KMnO}_{4}$ - oxidizable) & 147.2 \\
\hline Available $\mathrm{P} \mathrm{kg} \mathrm{ha}^{-1}$ ( $0.5 \mathrm{~N} \mathrm{NaHCO}_{3}$ - extractable) & 17.0 \\
\hline Available $\mathrm{K} \mathrm{kg} \mathrm{ha}^{-1}$ (1 N NH $\mathrm{N}_{4} \mathrm{OAc}$ - exchangeable) & 225.1 \\
\hline pH (1:2.5 soil: water) & 7.5 \\
\hline $\mathrm{EC}\left(\mathrm{dSm}^{-1}\right.$ at $\left.25^{\circ} \mathrm{C}\right)$ & 0.33 \\
\hline \multicolumn{2}{|l|}{ Microbiological properties } \\
\hline $\begin{array}{l}\text { Microbial biomass C ( } \mu \mathrm{gBCg}^{-1} \text { soil) } \\
\text { (Nunan et al. 1998) }\end{array}$ & 84.3 \\
\hline $\begin{array}{l}\text { Dehydrogenase activity ( } \mu \text { g TPF g }{ }^{-1} \text { soil day }{ }^{-1} \text { ) } \\
\text { (Casida et al. 1964) }\end{array}$ & 26.3 \\
\hline $\begin{array}{l}\text { FDA hydrolysis }\left(\mathrm{A}_{490} \mu \mathrm{g} \text { Fluorescein } \mathrm{g}^{-1} \text { soil } \mathrm{hr}^{-1} \text { ) }\right. \\
\text { (Green et al. 2006) }\end{array}$ & 2.03 \\
\hline
\end{tabular}

*The physical, chemical and micro-biological properties of soil at the initiation of the rainy season trial in 2010 . 


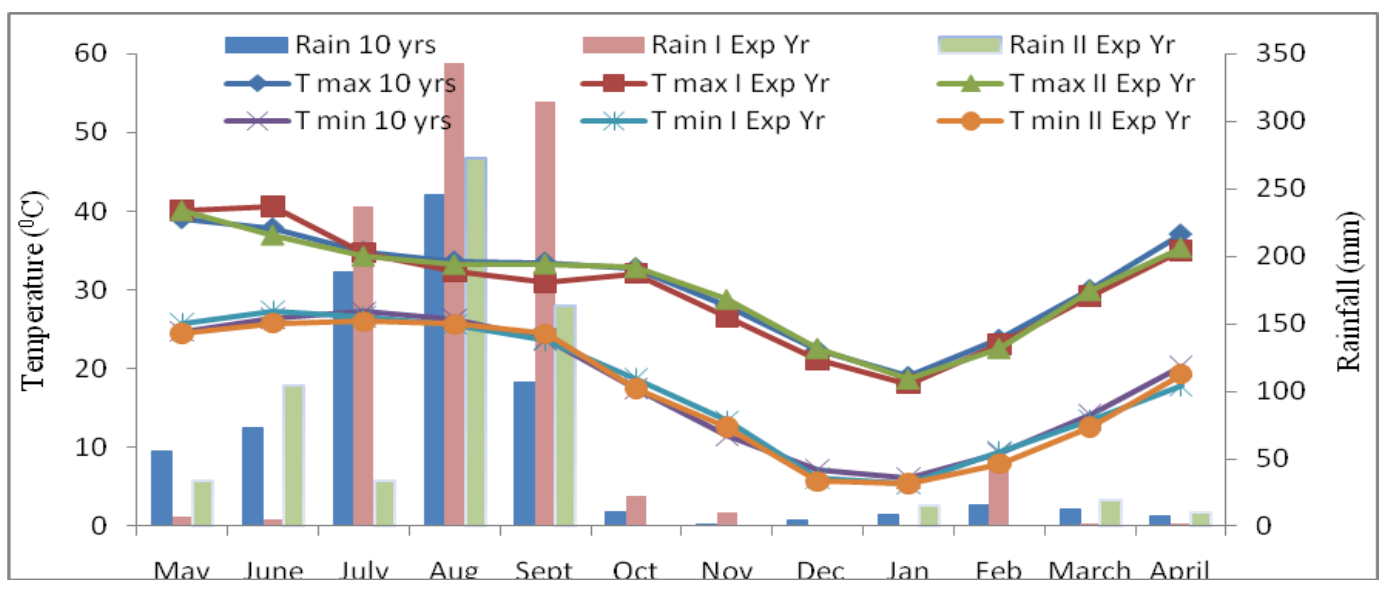

Figure 1. Comparison of mean monthly maximum and minimum temperature, and mean monthly total rainfall for last 10 years (2000-2009) with those for the experimental years (2010-11 and 2011-12).

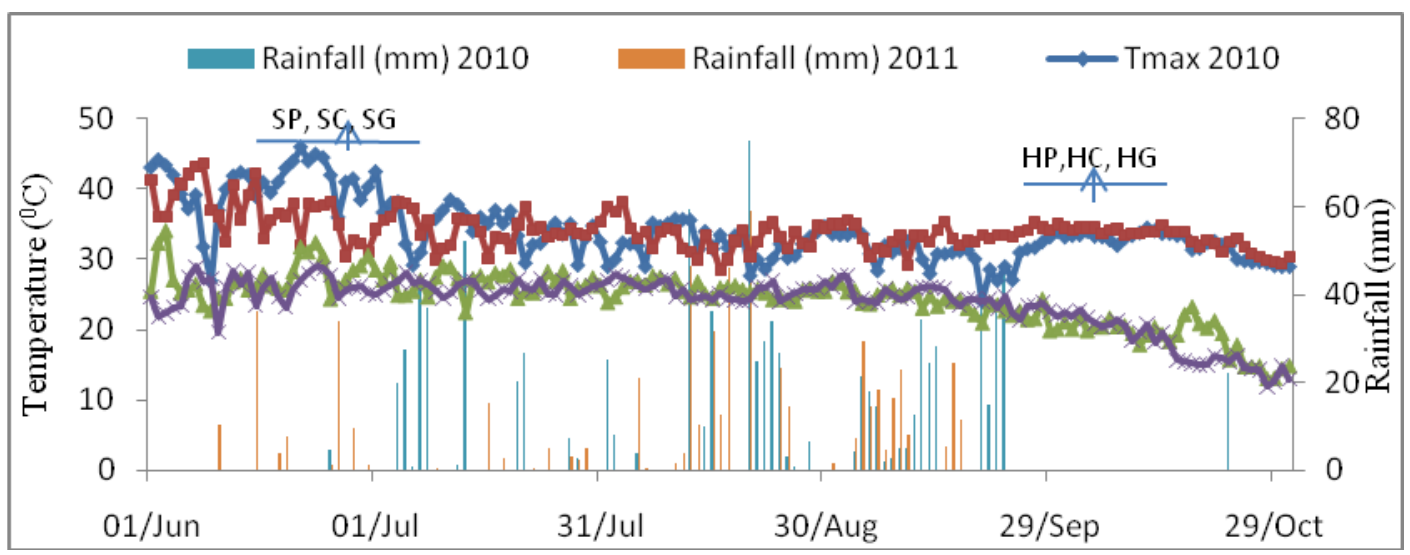

Figure 2. Daily variations in temperatures and rainfall during the growing period of rainy-season crops (Arrows indicate sowing and harvesting dates. SP, SC and SG: sowing of pearlmillet, clusterbean, and greengram; HP, HC and HG: harvesting of pearlmillet, clusterbean and greengram)

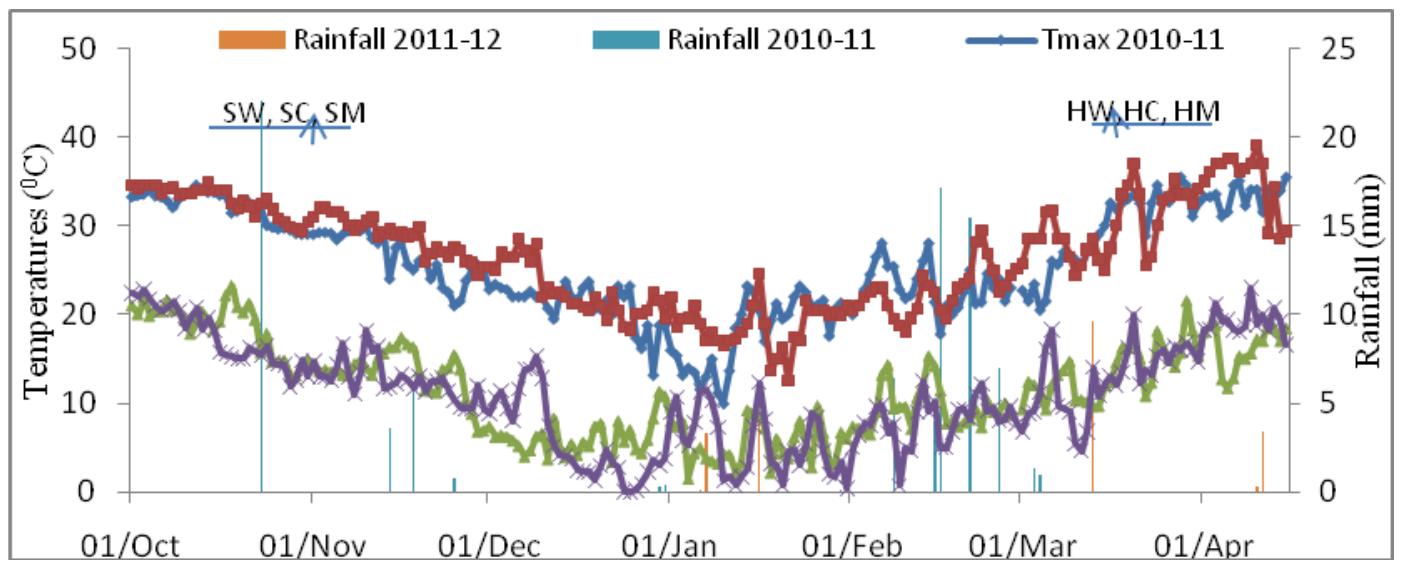

Figure 3. Daily variations in temperatures and rainfall during the growing period of winter-season crops. Arrows indicate the sowing and harvesting dates. SW, SC and SM: sowing of wheat, chickpea, and mustard; HW, HC and HM: harvesting of wheat, chickpea and mustard). 


\subsection{Treatments details}

Initially, the field was Laser Land Leveled in November 2009 and a uniformity trial was conducted by growing wheat cultivar 'PBW-175'. Thereafter, continuous zero-tillage was followed till the establishment of the experimental crops under rainfed conditions. Pearlmillet, clusterbean and greengram were grown during rainy-season under no-residue, crop residues@5.0tha-1 and Leucaena twigs@10.0 tha-1 (fresh weight) in a randomized complete block design (RCBD) with four replications in 2010. Subsequently, winter-season crops, viz., wheat, chickpea and mustard, were grown as successive crops with the same residue management practices in a layout following strip and strip-split plot designs with the same replicas on the two respective seasons and years.

Three crops each in rainy season (pearlmillet, clusterbean and greengram) and winter season (wheat, chickpea and mustard) were grown. Thus, there were the following nine cropping systems:

i. Pearlmillet-wheat

ii. Pearlmillet-chickpea

iii. Pearlmillet-mustard

iv. Clusterbean- wheat

v. Clusterbean-chickpea

vi. Clusterbean-mustard

vii. Greengram-wheat

viii. Greengram-chickpea

ix. Greengram-mustard

Three treatments of mulch cover, viz., no residue, crop residue and Leucaena twigs were maintained. Residues of rainy-season crops @ 5.0 t ha-1 were retained at harvest and spread as mulch at sowing of winter-season crops in the respective plots. Similarly, the residues of winter-season crops were spread and retained as mulch @ 5.0 t ha-1 at sowing of rainyseason crops. The above-ground portion of crop residues was removed from the no-residue and Leucaena twigs applied plots. Leucaena twigs were applied @10.0 t ha-1 (fresh weight with moisture of 67 $\%$ w/w) immediately after sowing of crops in both seasons. The crop residues and Leucaena twigs were retained on the soil surface and all crops were grown exclusively under zero-till condition throughout the experimenation.

\subsection{Crop management}

Rainy season crops: Sowing of pearlmillet, clusterbean and greengram was carried out with a zerotill seed-cum-fertilizer drill known as 'Happy Seeder' (Sidhu et al. 2007) at row spacing of $40 \mathrm{~cm}, 40 \mathrm{~cm}$ and $20 \mathrm{~cm}$, respectively. The seed-drill was calibrated suitably to adjust the seed rate @ 5, 30 and 40 kg ha-1, respectively, for the above crops. Pearlmillet seeds were small, so they were uniformly mixed with diammonium phosphate (DAP) and placed together in the seed-box of
Happy Seeder (Sidhu et al. 2007). Seeds of greengram were treated with chloropyriphos@ 2 ml kg-1 seed for $30 \mathrm{~min}$ before sowing. The clusterbean seeds were also pre-treated with fungicide thimaethoxam. The crops were supplied with NPK fertilizers as per the recommended doses, i.e., 60:40:20 kg ha-1 N-P2O5K2O for pearlmillet and 20:40:20 kg ha-1 N-P2O5$\mathrm{K} 2 \mathrm{O}$ for both clusterbean and greengram. All fertilizers were applied as basal for clusterbean and greengram, whereas for pearlmillet, 50\% $\mathrm{N}$ (through DAP and urea), along with full P (through DAP) and K (muriate of potash), was applied as basal. The remainder $\mathrm{N}$ (as urea) was top-dressed during the period of active growth, which coincided with the occurrence of rainfall. Plant population was adjusted to about 50 plants $\mathrm{m}-2$ for pearlmillet and clusterbean $(40 \mathrm{~cm} \times 5 \mathrm{~cm})$ and 100 plants $\mathrm{m}-2$ for greengram $(20 \mathrm{~cm} \times 5 \mathrm{~cm})$ about 15 days after sowing (DAS). Pendimethalin, a pre-emergence herbicide@0.75 kg ha-1 in 500 liters of water, was applied a day after sowing of the crops. In 2011, clusterbean under crop-residue treatments was heavily infested with Cyperus iria, which was controlled by hand weeding. Pearlmillet was highly effective in suppressing all weed species; therefore, the weed infestation in pearlmillet plots was negligible.

Winter-season crops: Sowing of wheat, chickpea and mustard was carried out using row spacing of 20, 40 and $40 \mathrm{~cm}$, respectively, with a well-calibrated Happy Seeder (Sidhu et al. 2007). Wheat was sown at a seed rate of $120 \mathrm{~kg}$ ha-1, whereas the seed rate for chickpea was $80 \mathrm{~kg}$ ha- 1 and that for mustard $4 \mathrm{~kg}$ ha- 1 . Wheat seed was treated with chloropyriphos@2 ml kg-1 seed for one hour prior to sowing. The NPK fertilizers were applied @ 80:60:40 kg N-P2O5-K2O ha-1 for wheat and mustard, and 20:40:20 kg N-P2O5-K2O ha-1 for chickpea, as recommended for the rainfed crops. Fifty percent of $\mathrm{N}$, along with full $\mathrm{P}$ and $\mathrm{K}$, was applied as basal dose for wheat and mustard; for chickpea, full dose of all the nutrients was applied basally. The remainder amount of $\mathrm{N}$ was top-dressed in wheat and mustard on the second day following the occurrence of rainfall. As for the rainy-season crops, DAP was mixed with mustard seed in the seed box of the Happy Seeder, and the fertilizers and seeds were drilled together. The remainder $\mathrm{N}$ (as urea) was top-dressed at maximum vegetative growth stage.

Because of the occurrence of late monsoon rainfall just after sowing of the winter crops on 22 October 2010, germination of all crops was good. Thinning was carried out in mustard to maintain a plant to plant spacing of 8-10 cm. In the second year (2011-12), mustard and chickpea sown on 3 October, 2011 did not germinate because of scanty soil moisture coupled with high temperatures and evaporation throughout October. Therefore, limited irrigation (about $200 \mathrm{~m} 3$ of water ha-1) was applied along the seed rows 20 DAS to obtain a uniform plant stand. Further, the gravimetric soil moisture in the surface soil $(0-15 \mathrm{~cm})$ at the end of 
October was only $7-8 \%$ in the plots to be sown with wheat. Therefore, a pre-sowing flood irrigation equivalent to $7.0 \mathrm{~cm}$ was applied to these plots, and after attainment of optimum soil moisture, the wheat crop was sown on 11 November 2011.

\subsection{Seed and stover / stalk yield}

Pearlmillet was harvested when ear-heads had turned whitish brown and grains had become relatively hard. Greengram pods were hand-picked twice: first, when $>60 \%$ pods had changed to blackish brown color (70-75 DAS), and second, when $75 \%$ of leaves had abscised and when almost all pods had matured. The green and tender pods of clusterbean were harvested twice (at an interval of 4-5 days) for vegetable purposes 80 DAS. A net plot size of $25 \mathrm{~m} 2$ was used for the rainy season crops in the first year; two border rows were left on either side along the length of the plots and $1.0 \mathrm{~m}$ on the other side of the plot. The ear-heads of pearlmillet were harvested manually with a serrated sickle. Threshing of thoroughly dried heads of pearlmillet and pods of greengram was carried out with an Almaco Pullman Thresher (Sidhu et al. 2007).

A net plot size of $10 \mathrm{~m} 2$ was used for all winter crops. Samples for mustard, wheat and chickpea were taken at maturity from the third week of March to the first week of April from the sampling area in the middle of the plot, avoiding the border rows. The grain and stalk samples were left in the field for 3-4 days for sun drying, after which, bundle weights were recorded. Threshing was carried out with the same Pullman Thresher as used for the rainy-season crops. Grains were separated, cleaned and weighed separately from each net plot. The weight of straw and stalk was recorded by subtracting the grain weight from the bundle weight.

\subsection{Assessment of equivalent and system yields}

Pearlmillet-equivalent yield (PEY) of rainy-season crops was estimated by multiplying the minimum support price (MSP) of clusterbean and greengram (Table 2) with the ratio of their economic yield and MSP of pearlmillet using the following equation:

PEY $=$ [Yield of pearlmillet $+\{$ (Yield of clusterbean and greengram $\times$ price of clusterbean and greengram) $\div$ Price of pearlmillet $\}$ ]

Similarly, wheat-equivalent yield (WEY) of winterseason crops was calculated by multiplying the ratio of seed yields of chickpea and mustard to the MSP of wheat with the MSP of chickpea and mustard (Table 2) as shown in following equation:

WEY $=$ [Yield of wheat $+\{($ Yield of mustard and chickpea $\times$ price of mustard and chickpea) $\div$ Price of wheat\}]
Total system productivity was determined as total pearlmillet-equivalent yield (TPEY), wherein, PEY is added to the quotient of WEY divided by the price of pearlmillet.

$\mathrm{TPEY}=[\mathrm{PEY}+(\mathrm{WEY} \div$ price of pearlmillet $)]$

Table 2. Prices of produce used in economic analysis (minimum support price (MSP) for grain or seed, and the prevailing market rate for by-product during experimentation [Indian Rupees (INRs) $\mathrm{t}^{-1}$ ] $\dagger$

\begin{tabular}{|c|c|c|c|}
\hline Rainy season crops & Products & 2010 & 2011 \\
\hline \multicolumn{4}{|l|}{ Pearlmillet } \\
\hline & Grain & 8800 & 9800 \\
\hline & Stover & 400 & 500 \\
\hline \multicolumn{4}{|l|}{ Clusterbean } \\
\hline & Green pods & 5000 & 8000 \\
\hline & Stover & 400 & 500 \\
\hline \multicolumn{4}{|l|}{ Greengram } \\
\hline & Seed & 31700 & 35000 \\
\hline & Stover & 400 & 500 \\
\hline Winter season crops & Products & 2010-11 & 2011-12 \\
\hline \multicolumn{4}{|l|}{ Wheat } \\
\hline & Grain & 10200 & 12850 \\
\hline & Straw & 500 & 600 \\
\hline \multicolumn{4}{|l|}{ Chickpea } \\
\hline & Seed & 21500 & 28000 \\
\hline & Stover & 500 & 600 \\
\hline \multicolumn{4}{|l|}{ Mustard } \\
\hline & Seed & 18500 & 25000 \\
\hline & Stover & 500 & 600 \\
\hline
\end{tabular}

\subsection{Economic analysis}

Economics of different treatments mainly cost of cultivation, gross and net returns and B : C ratio was determined by considering the cost of inputs and operations, and price of output (grain and by-product yields).

The details regarding output values and input costs as common cost and total cost of cultivation per treatment are presented in Tables 2-5.

Gross and net returns, and B : C ratio were estimated for each treatment on the basis of total cost of cultivation, economic output and market prices of the various commodities.

\subsection{Statistical analysis}


The experimental data recorded on yield of individual crops, systems yield as pearlmillet, wheat and total pearlmillet equivalent yields, systems economics were subjected to statistical analysis by using the analysis of variance (ANOVA) technique, and the significance tested was tested using F-test (Gomez and Gomez, 1984).
Least significant differences (LSDD; $\mathrm{p}<0.05$ ) were calculated for different variables to estimate differences between treatment means.

Table 3. Estimation of common cost of cultivation of different rainy-season crops (INRs ha-1 $)^{\S}$

\begin{tabular}{|c|c|c|c|c|c|c|}
\hline \multirow[t]{2}{*}{ Particulars } & \multicolumn{2}{|c|}{ Pearlmillet } & \multicolumn{2}{|c|}{ Clusterbean } & \multicolumn{2}{|c|}{ Greengram } \\
\hline & 2010 & 2011 & 2010 & 2011 & 2010 & 2011 \\
\hline Seed & 200 & 250 & 2500 & 2700 & 2500 & 2700 \\
\hline Sowing with Happy seeder & 1000 & 1250 & 1000 & 1250 & 1000 & 1250 \\
\hline Fertilizer $\left(\mathrm{kg} \mathrm{ha}^{-1}\right)$ & \multicolumn{2}{|c|}{ NPK::60:40:20 } & \multicolumn{2}{|c|}{ NPK::20:40:20 } & \multicolumn{2}{|c|}{ NPK::20:40:20 } \\
\hline $\mathrm{N}$ & 750 & 850 & 250 & 300 & 250 & 300 \\
\hline $\mathrm{P}$ & 950 & 1200 & 950 & 1200 & 950 & 1200 \\
\hline $\mathrm{K}$ & 500 & 600 & 500 & 600 & 500 & 600 \\
\hline \multicolumn{7}{|l|}{ Herbicide } \\
\hline Pre-sowing & 0 & 350 & 0 & 350 & 0 & 350 \\
\hline After sowing & 350 & 350 & 350 & 350 & 350 & 350 \\
\hline Application & 150 & 400 & 150 & 400 & 150 & 400 \\
\hline Gap filling and thinning & 450 & 600 & 300 & 400 & 300 & 400 \\
\hline Hand weeding & 0 & 0 & 0 & 1000 & 0 & 0 \\
\hline Insecticide & 0 & 0 & 450 & 600 & 450 & 600 \\
\hline Application & 0 & 0 & 300 & 400 & 300 & 400 \\
\hline Harvesting & 1500 & 2000 & 1500 & 2000 & 1500 & 2000 \\
\hline Threshing & 750 & 1000 & 0 & 0 & 450 & 600 \\
\hline Bird watching (15 days) & 2250 & 3000 & 0 & 0 & 0 & 0 \\
\hline Rental value of land (6 & 1000 & 1000 & 1000 & 1000 & 1000 & 1000 \\
\hline \multicolumn{7}{|l|}{ months @`2000/ha/annum) } \\
\hline Interest on loan (6\%) & 591 & 771 & 555 & 693 & 582 & 729 \\
\hline Grand total & 10441 & 13621 & 9805 & 13303 & 10282 & 12879 \\
\hline
\end{tabular}

Note: Labor wage- 2010-11 @ INRs 150 man-day ${ }^{-1}$, 2011-12 @ INRs 200 man-day ${ }^{-1} \S$ (1 US\$ = INRs 60.00) 
Table 4. Estimation of common cost of cultivation of winter-season season crops (INRs ha $\left.{ }^{-1}\right)^{\S}$

\begin{tabular}{|c|c|c|c|c|c|c|}
\hline \multirow[t]{2}{*}{ Particulars } & \multicolumn{2}{|c|}{ Wheat } & \multicolumn{2}{|c|}{ Chickpea } & \multicolumn{2}{|c|}{ Mustard } \\
\hline & $2010-11$ & $2011-12$ & $2010-11$ & $2011-12$ & $2010-11$ & $2011-12$ \\
\hline Seed & 2250 & 2500 & 2500 & 2700 & 500 & 600 \\
\hline Sowing (Turbo-seeder) & 1000 & 1250 & 1000 & 1250 & 1000 & 1250 \\
\hline Fertilizer (kg ha $\left.{ }^{-1}\right)$ & \multicolumn{2}{|c|}{ NPK::60:40:20 } & \multicolumn{2}{|c|}{ NPK::20:40:20 } & \multicolumn{2}{|c|}{ NPK::60:40:20 } \\
\hline $\mathrm{N}$ & 750 & 850 & 250 & 300 & 750 & 850 \\
\hline $\mathrm{P}$ & 950 & 1000 & 950 & 1000 & 950 & 1000 \\
\hline K & 500 & 600 & 500 & 600 & 500 & 600 \\
\hline \multicolumn{7}{|l|}{ Herbicides and application } \\
\hline Pre-sowing & 0 & 350 & 0 & 350 & 0 & 350 \\
\hline After-sowing & 0 & 350 & 0 & 0 & 0 & 0 \\
\hline Application & 0 & 400 & 0 & 200 & 0 & 200 \\
\hline Irrigation cost & 0 & 600 & 0 & 300 & 0 & 300 \\
\hline Gap filling and thinning & 0 & 0 & 0 & 600 & 450 & 600 \\
\hline Insecticide cost & 0 & 0 & 0 & 500 & 0 & 500 \\
\hline Application & 0 & 0 & 0 & 200 & 0 & 200 \\
\hline Harvesting & 1500 & 2000 & 1200 & 1600 & 1500 & 2000 \\
\hline Threshing & 750 & 1000 & 450 & 600 & 750 & 1000 \\
\hline Bird watching (15 days) & 2250 & 3000 & 2250 & 3000 & 2250 & 3000 \\
\hline Rental value of land (6 months @`2000/ha/annum) & 1000 & 1000 & 1000 & 1000 & 1000 & 1000 \\
\hline Interest on loan (6\%) & 657 & 894 & 606 & 852 & 579 & 807 \\
\hline Grand total & 11607 & 15794 & 10706 & 15052 & 10229 & 14257 \\
\hline
\end{tabular}

Note: Labor wage- 2010-11@ INRs 150 man-day $^{-1}$, 2011-12 @ INRs 200 man-day ${ }^{-1}$ (1 US\$ = INRs 60.00) 
Table 5. Variable cost of cultivation for different treatments (INRs ha-1 $)^{\S}$

$\begin{array}{cccc}\text { Particulars } & \text { Crop residues @ } 5 \text { t ha }^{-1} \text { dry biomass } & \text { Leucaena twigs @ } 10 \mathrm{t} \mathrm{ha}^{-1} \text { green biomass } \\ & 2010-11 & 2011-12 & 2010-11\end{array}$

\section{Rainy season crops}

$\begin{array}{ccccc}\text { i. Pearlmillet } & 2950 & 3600 & 1500 & 2000 \\ \text { ii. Clusterbean } & 2950 & 3600 & 1500 & 2000 \\ \text { iii. Greengram } & 2950 & 3600 & 1500 & 2000\end{array}$

2. Winter season crops

$\begin{array}{ccccc}\text { i. Wheat } & 2450 & 3100 & 1500 & 2000 \\ \text { ii. Chickpea } & 2450 & 3100 & 1500 & 2000 \\ \text { iii. Mustard } & 2450 & 3100 & 1500 & 2000\end{array}$

Note: Crop residues application cost @ 3 man-days ha- ${ }^{-1}$ with Happy Seeder; Leucaena twigs mulching application cost @ 10 man-days ha- ${ }^{-1} \S(1$ US\$ = INRs 60.00)

\section{Results}

\subsection{Weather details and crop productivity}

The climate of New Delhi is of semi-arid type, with hot and dry summers and cold winters. It is categorized as the 'Trans-Gangetic plains' agro-climatic zone (AEZ). The 10-year mean monthly total rainfall and mean monthly maximum and minimum temperatures (2000-2009), and the monthly total rainfall and monthly mean maximum and minimum temperatures for the experimental years (2010-11 and 2011-12) are shown in Figure 1-3. The data revealed that the mean maximum temperatures ranged from 37-380C during May-June, whereas the mean minimum temperatures ranged from 6-80C during December-January. Likewise, 10-years mean monthly total rainfall ranged from a few mm during November-January to as high as $100-250 \mathrm{~mm}$ during July-September. Around $80 \%$ of the total annual rainfall occurred during July-September and the remainder $20 \%$ occurred in the other months, with negligible rainfall occurring in the winter season. The monthly total rainfall for July-September was higher for both the experimental years than the 10-years mean values, whereas the trends were not consistent for other months, and especially for winter months. Maximum temperatures were generally higher than the long-term mean temperatures, which; however, was not the case for the minimum temperatures. Analysis of weather conditions across the 10 -years period indicated that crop production during the rainy-season (JulySeptember) was more assured, but that during the winter (October-
April), it was risky and dependent primarily on the occurrence of rainfall. The meteorological data recorded daily for the rainy and winter seasons of 2010-11 and 2011-12 from the Meteorological Observatory of the Institute are graphically presented in Figures 2 and 3. In 2010, $953.7 \mathrm{~mm}$ of rainfall was received, whereas it was much less $(668.7 \mathrm{~mm})$ in 2011, and also lower than the 10-year average $(739 \mathrm{~mm})$. Rainfall during winter was well distributed in 2010-11 (10 rainy days, $85.5 \mathrm{~mm}$ ); it was much less (three rainy days, $34.1 \mathrm{~mm}$ ) in 2011-12. During winter, October 2011 had the highest maximum temperature, resulting in high evapo-transpiration. Further, minimum temperature for a few days during December-January in 2011-12 dropped down to 00C, which caused some frost injury on the mustard crop. Thus, the two experimental years had quite distinct weather conditions.

\subsection{System productivity in terms of pearlmillet, wheat and total pearlmillet equivalent yields}

Grain yield expressed as pearlmillet-equivalent yield for summer crops and as wheat-equivalent yield for winter crops, and system productivity as total pearlmillet-equivalent yield showed significant variation between the two years (Tables 6-8). Pearlmilletequivalent yield of the rainy-season crops during 2010 showed the highest yield with clusterbean under Leucaena twigs (5.72 t ha-1), followed by crop residue retention (4.69 t ha-1) (Table 6). Similar to summer 
season crops, the yield of winter-season crops expressed in wheat-equivalent yield was significantly higher under mustard after Leucaena twigs with clusterbean as the preceding rainy-season crop than the pearlmillet and greengram (Table 7). The wheat equivalent yield was significantly higher in 2010-11 than in 2011-12 because of higher mustard yield in former year. Chickpea followed mustard in wheat-equivalent yield in 2010-11, but wheat followed mustard in 2011-12. Results further showed the lowest pearlmillet-equivalent yield under no residue for pearlmillet (1.44 $\mathrm{t}$ ha-1), followed by greengram (2.69 t ha-1). Although greengram fetched higher market price, it was not superior to clusterbean because of less greengram seed yield and high clusterbean green pod yield. A similar trend was found in both years, but the productivity was lower in 2011 because of erratic rainfall pattern. In 2011, pearlmilletequivalent yields after chickpea were the highest but the lowest after mustard (Table 6).

Table 6. Pearlmillet-equivalent yield (t ha- 1 crop-1 season-1) of rainy-season crops (A) under crop residues and Leucaena twigs after the winter-season crops

\begin{tabular}{|c|c|c|c|c|c|c|c|c|c|}
\hline \multirow{2}{*}{$\begin{array}{c}\text { Residue } \\
\text { management (B)/ } \\
\text { winter-crops (C) }\end{array}$} & \multicolumn{3}{|c|}{ 2010ף } & \multicolumn{6}{|c|}{2011} \\
\hline & $\begin{array}{l}\text { Pearl } \\
\text { Millet }\end{array}$ & $\begin{array}{c}\text { Cluster } \\
\text { Bean }\end{array}$ & $\begin{array}{l}\text { Green } \\
\text { gram }\end{array}$ & $\begin{array}{l}\text { Pearl } \\
\text { millet }\end{array}$ & $\begin{array}{c}\text { Cluster } \\
\text { bean }\end{array}$ & \multicolumn{4}{|c|}{ Green gram } \\
\hline \multicolumn{10}{|l|}{ After wheat } \\
\hline No residue & 1.44 & 4.35 & 2.69 & 1.17 & 4.19 & & & 1.58 & \\
\hline Crop residue & 1.73 & 4.69 & 3.31 & 1.34 & 5.68 & & & 2.15 & \\
\hline $\begin{array}{l}\text { Leucaena twigs } \\
\text { After chickpea }\end{array}$ & \multicolumn{8}{|c|}{ After chickpea } & \\
\hline No residue & & & & 1.32 & 4.52 & & & 1.61 & \\
\hline Crop residue & & & & 1.95 & 5.63 & & & 2.49 & \\
\hline $\begin{array}{l}\text { Leucaena twigs } \\
\text { After mustard }\end{array}$ & & & & 1.56 & 5.59 & & & 2.78 & \\
\hline No residue & & & & 1.33 & 3.53 & & & 1.71 & \\
\hline Crop residue & & & & 1.45 & 4.49 & & & 1.81 & \\
\hline Leucaena twigs & & & & & 4.68 & & & & \\
\hline & $\begin{array}{c}\text { A } \\
0.21\end{array}$ & $\begin{array}{c}\text { B } \\
0.36\end{array}$ & $\begin{array}{c}\mathrm{A} \times \mathrm{B} \\
0.51\end{array}$ & $\begin{array}{c}\mathrm{A} \\
0.18\end{array}$ & $\begin{array}{c}\text { B } \\
0.18\end{array}$ & $\begin{array}{c}\mathrm{C} \\
0.13\end{array}$ & $\begin{array}{c}A \times B \\
0.29\end{array}$ & $\begin{array}{c}A \times C \\
0.22\end{array}$ & $\begin{array}{c}\mathrm{B} \times \mathrm{C} \\
0.22\end{array}$ \\
\hline $\operatorname{LSD}(\mathrm{P}<0.05)$ & & & & & & & & & \\
\hline
\end{tabular}

IThere were only three treatments during rainy-season of 2010

In the winter season, the wheat-equivalent yield for chickpea and mustard was significantly higher under Lecuaena twigs and crop residue than the no residue (Table 7). Wheat did not perform well in 2010-11 because of less residual soil moisture, but it did well in 2011-12, which in turn led to higher wheat-equivalent yield.

The performance of different crops in terms of total system productivity grown in sequence under the two important CA-based technologies (zero-till and surface mulching with crop residues and Leucaena twigs grown on the farm boundaries was evaluated in total pearlmillet equivalent yields (Table 8).

In 2010-11, the significantly higher yield (10.53 t ha-1) with clusterbean-mustard system under Leucaena twigs than the clusterbean-mustard cropping system under crop residue (9.13 t ha-1). In contrast, in 2011-12, pearlmillet-equivalent yield was significantly higher under clusterbean-wheat system with crop residue (9.75 t ha-1) than the clusterbean-chickpea under Leucaena twigs (9.03 tha-1).

Higher wheat yield in 2011-12 was contributed to higher pearlmillet-wheat equivalent yield under clusterbean as the preceding crop. Relative to pearlmillet-equivalent system yield, clusterbeanmustard system under Leucaena twigs and crop residue, and clusterbean-wheat system with crop residue and clusterbean-chickpea system with Leucaena twigs resulted in higher system productivity. 
Table 7. Wheat-equivalent yield ( $\mathrm{t} \mathrm{ha}^{-1} \mathrm{crop}^{-1}$ season $^{-1}$ ) of winter-season crops (C) under crop residues and Leucaena twigs after the rainy-season crops

\begin{tabular}{|c|c|c|c|c|c|c|c|c|c|c|c|c|}
\hline \multirow{2}{*}{\multicolumn{3}{|c|}{$\begin{array}{l}\text { Residue management (B)/ } \\
\text { rainy-crops (A) }\end{array}$}} & \multicolumn{4}{|c|}{$2010-11$} & & \multicolumn{5}{|c|}{$2011-12$} \\
\hline & & & Wheat & $\begin{array}{c}\text { Chick } \\
\text { pea }\end{array}$ & \multicolumn{2}{|c|}{ Mustard } & & $\begin{array}{l}\text { Whe } \\
\text { at }\end{array}$ & $\begin{array}{l}\text { Chic } \\
\text { kpea }\end{array}$ & \multicolumn{2}{|c|}{ Mustard } & \\
\hline \multicolumn{13}{|c|}{ After pearl millet } \\
\hline \multicolumn{3}{|c|}{ No residue } & 0.51 & 1.88 & \multicolumn{2}{|c|}{2.43} & & 1.07 & 1.55 & \multicolumn{2}{|c|}{1.43} & \\
\hline \multirow{2}{*}{\multicolumn{3}{|c|}{$\begin{array}{l}\text { Leucaena twigs } \\
\text { After cluster bean }\end{array}$}} & 1.16 & 2.90 & \multicolumn{2}{|c|}{3.29} & & 2.71 & 3.19 & \multicolumn{2}{|c|}{2.68} & \\
\hline & & & 1.12 & 3.53 & \multicolumn{2}{|c|}{4.08} & & 2.20 & 2.19 & \multicolumn{2}{|c|}{1.94} & \\
\hline \multicolumn{3}{|c|}{ No residue } & 0.58 & 1.23 & \multicolumn{2}{|c|}{1.34} & & 1.06 & 1.39 & \multicolumn{2}{|c|}{1.87} & \\
\hline Crop re & & & 1.24 & 2.11 & \multicolumn{2}{|c|}{3.83} & & 2.94 & 2.17 & \multicolumn{2}{|c|}{2.46} & \\
\hline \multicolumn{3}{|c|}{$\begin{array}{l}\text { Leucaena twigs } \\
\quad \text { After green gram }\end{array}$} & 1.03 & 2.55 & \multicolumn{2}{|c|}{4.15} & & 3.29 & 2.70 & \multicolumn{2}{|c|}{3.77} & \\
\hline No res & & & 0.84 & 1.48 & \multicolumn{2}{|c|}{2.70} & & 1.72 & 1.49 & \multicolumn{2}{|c|}{1.58} & \\
\hline Crop re & & & 1.33 & 2.39 & \multirow{2}{*}{\multicolumn{2}{|c|}{$\begin{array}{l}4.04 \\
3.59\end{array}$}} & & 3.32 & 2.90 & \multicolumn{2}{|c|}{$\begin{array}{l}3.04 \\
2.19\end{array}$} & \\
\hline Leucaenc & & & 1.16 & 2.77 & & & & 2.44 & 2.04 & \multicolumn{2}{|c|}{2.19} & \\
\hline \multicolumn{3}{|l|}{ Treatment } & & & & & & & & & & \\
\hline Source & A & B & $\mathrm{C}$ & $\mathrm{A} \times \mathrm{B}$ & $A \times C$ & $\mathrm{~B} \times \mathrm{C}$ & A & B & $\mathrm{C}$ & $\mathrm{A} \times \mathrm{B}$ & $A \times C$ & $\mathrm{~B} \times \mathrm{C}$ \\
\hline $\begin{array}{c}\text { LSD } \\
(\mathrm{P}<0.05)\end{array}$ & 0.05 & 0.02 & 0.12 & 0.29 & 0.21 & 0.21 & 0.16 & NS & 0.11 & 0.25 & 0.19 & 0.19 \\
\hline
\end{tabular}

I The interaction effect of rainy season crops (A), residue management (B) and winter season crops (C)

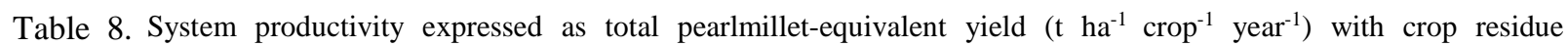
incorporation and Leucaena twigs

\begin{tabular}{|c|c|c|c|c|c|c|c|c|c|c|c|c|}
\hline \multirow{2}{*}{$\begin{array}{c}\text { Residue } \\
\text { management }(B) / \\
\text { Winter - crops (C) }\end{array}$} & \multicolumn{6}{|c|}{ 2010-11 } & \multicolumn{6}{|c|}{ 2011-12 } \\
\hline & $\begin{array}{l}\text { Pearl } \\
\text { Millet }\end{array}$ & & $\begin{array}{l}\text { lluster } \\
\text { bean }\end{array}$ & $\begin{array}{l}\text { Gree } \\
\text { gran }\end{array}$ & & Mean & $\begin{array}{l}\text { Pearl } \\
\text { millet }\end{array}$ & & $\begin{array}{l}\text { Cluster } \\
\text { bean }\end{array}$ & & $\begin{array}{l}\text { Green } \\
\text { gram }\end{array}$ & Mean \\
\hline & & & & & & & & & & & & \\
\hline No residue & 2.03 & & 5.02 & 3.6 & & 3.57 & 2.53 & & 6.17 & & 3.41 & 4.04 \\
\hline Crop residue & 3.07 & & 6.12 & 4.8 & & 4.68 & 4.80 & & 9.75 & & 5.56 & 6.70 \\
\hline $\begin{array}{l}\text { Leucaena twigs } \\
\text { After chickpec }\end{array}$ & 3.52 & & 6.92 & 4.3 & & 4.94 & 4.13 & & 8.93 & & 5.00 & 6.02 \\
\hline No residue & 3.61 & & 5.78 & 4.4 & & 4.60 & 2.66 & & 6.29 & & 4.00 & 4.32 \\
\hline Crop residue & 5.08 & & 7.13 & 6.0 & & 6.10 & 5.69 & & 8.39 & & 5.62 & 6.57 \\
\hline $\begin{array}{l}\text { Leucaena twigs } \\
\text { After mustard }\end{array}$ & 6.32 & & 8.67 & 6.2 & & 7.08 & 5.75 & & 9.03 & & 7.59 & 7.46 \\
\hline No residue & 4.26 & & 5.90 & 5.8 & & 5.33 & 3.52 & & 5.43 & & 3.73 & 4.23 \\
\hline Crop residue & 5.54 & & 9.13 & 7.9 & & 7.55 & 5.68 & & 8.19 & & 5.70 & 6.52 \\
\hline & 6.95 & & 10.53 & 7.2 & & 8.23 & 4.45 & & 7.29 & & 4.99 & 5.57 \\
\hline & A & B & $\mathrm{C}$ & $\begin{array}{r}\mathrm{Ax} \\
\mathrm{B}\end{array}$ & $\mathrm{Ax}$ & $\begin{array}{r}\text { B x } \\
\text { C }\end{array}$ & A & B & C & $A \times B$ & A $\times C$ & B x C \\
\hline $\operatorname{LSD}(\mathrm{P}<0.05)$ & 0.24 & 0.2 & 0.24 & 0.3 & 0.42 & 0.42 & 0.317 & 0.30 & 0.19 & 0.41 & 0.32 & 0.32 \\
\hline
\end{tabular}


Table 9. System economics of pearlmillet-based systems as influenced by residue management after winter-season crops 1

\begin{tabular}{|c|c|c|c|c|c|c|}
\hline \multirow[t]{2}{*}{ Treatment } & \multicolumn{3}{|c|}{$2010-11$} & \multicolumn{3}{|c|}{ 2011-12 } \\
\hline & $\begin{array}{c}\text { Cost of } \\
\text { cultivation } \\
\left(\times 10^{3} \text { INRs ha }^{-1}\right) \\
\end{array}$ & $\begin{array}{c}\text { Net returns } \\
\left(\times 10^{3} \text { INRs ha }^{-1}\right)\end{array}$ & $\begin{array}{l}\mathrm{B}: \mathrm{C} \\
\text { ratio }\end{array}$ & $\begin{array}{c}\text { Cost of } \\
\text { cultivation } \\
\left(\times 10^{3} \text { INRs ha }{ }^{-1}\right) \\
\end{array}$ & $\begin{array}{c}\text { Net returns } \\
\left(\times 10^{3} \text { INRs }\right. \\
\left.\text { ha }^{-1}\right) \\
\end{array}$ & $\mathrm{B}: \mathrm{C}$ ratio \\
\hline \multicolumn{7}{|c|}{ After wheat } \\
\hline No residue & 22.05 & 0.67 & 0.03 & 29.42 & -0.03 & 0.00 \\
\hline Crop residue & 27.45 & 6.35 & 0.23 & 36.12 & 20.09 & 0.56 \\
\hline Leucaena twigs & 25.05 & 11.92 & 0.48 & 33.42 & 15.56 & 0.47 \\
\hline \multicolumn{7}{|c|}{ After chickpea } \\
\hline No residue & 21.15 & 15.81 & 0.75 & 28.67 & 9.59 & 0.33 \\
\hline Crop residue & 26.55 & 24.52 & 0.92 & 35.37 & 32.60 & 0.92 \\
\hline Leucaena twigs & 24.15 & 37.16 & 1.54 & 32.67 & 17.42 & 0.53 \\
\hline \multicolumn{7}{|c|}{ After mustard } \\
\hline No residue & 20.67 & 21.66 & 1.05 & 27.88 & 8.86 & 0.32 \\
\hline Crop residue & 26.07 & 29.98 & 1.15 & 34.58 & 23.79 & 0.69 \\
\hline Leucaena twigs & 23.67 & 44.29 & 1.87 & 31.88 & 13.88 & 0.44 \\
\hline LSD $(\mathrm{P}<0.05)$ & - & 4.63 & 0.045 & - & 3.57 & 0.021 \\
\hline
\end{tabular}

I The interaction effect of winter season crops and residue management practices

Table 10. System economics of cluster bean-based systems as influenced by residue management after winter-season crops

\begin{tabular}{|c|c|c|c|c|c|c|}
\hline \multirow[t]{2}{*}{ Treatment } & \multicolumn{3}{|c|}{$2010-11$} & \multicolumn{3}{|c|}{ 2011-12 } \\
\hline & $\begin{array}{c}\text { Cost of } \\
\text { cultivation } \\
\left(\times 10^{3} \text { INRs ha }^{-1}\right) \\
\end{array}$ & $\begin{array}{c}\text { Net returns } \\
\left(\times 10^{3} \text { INRs ha }^{-1}\right)\end{array}$ & $\begin{array}{l}\mathrm{B}: \mathrm{C} \\
\text { ratio }\end{array}$ & $\begin{array}{c}\text { Cost of } \\
\text { cultivation } \\
\left(\times 10^{3} \text { INRs ha }^{-1}\right) \\
\end{array}$ & $\begin{array}{c}\text { Net returns } \\
\left(\times 10^{3} \text { INRs ha }^{-1}\right)\end{array}$ & $\begin{array}{c}\mathrm{B}: \mathrm{C} \\
\text { ratio }\end{array}$ \\
\hline \multicolumn{7}{|c|}{ After wheat } \\
\hline No residue & 21.41 & 25.80 & 1.20 & 29.10 & 27.95 & 0.96 \\
\hline Crop residue & 26.81 & 31.60 & 1.18 & 35.80 & 61.77 & 1.73 \\
\hline Leucaena twigs & 24.41 & 40.85 & 1.67 & 33.10 & 73.40 & 2.22 \\
\hline \multicolumn{7}{|c|}{ After chickpea } \\
\hline No residue & 20.51 & 33.16 & 1.62 & 28.36 & 37.12 & 1.31 \\
\hline Crop residue & 25.91 & 40.28 & 1.55 & 35.06 & 52.25 & 1.49 \\
\hline Leucaena twigs & 23.51 & 56.61 & 2.41 & 32.36 & 62.75 & 1.94 \\
\hline \multicolumn{7}{|c|}{ After mustard } \\
\hline No residue & 20.03 & 35.23 & 1.76 & 27.56 & 34.75 & 1.26 \\
\hline Crop residue & 25.43 & 59.99 & 2.36 & 34.26 & 46.93 & 1.37 \\
\hline Leucaena twigs & 23.03 & 75.51 & 3.28 & 31.56 & 68.43 & 2.17 \\
\hline LSD $(\mathrm{P}<0.05)$ & - & 6.73 & 0.067 & - & 5.82 & 0.052 \\
\hline
\end{tabular}

I The interaction effect of winter season crops and residue management practices 
Table 11. . System economics of greengram-based systems as influenced by residue management after winter-season crops $\mathbb{1}$

\begin{tabular}{|c|c|c|c|c|c|c|}
\hline \multirow[t]{2}{*}{ Treatment } & \multicolumn{3}{|c|}{$2010-11$} & \multicolumn{3}{|c|}{ 2011-12 } \\
\hline & $\begin{array}{c}\text { Cost of } \\
\text { cultivation } \\
\left(\times 10^{3} \text { INRs ha }^{-1}\right) \\
\end{array}$ & $\begin{array}{c}\text { Net returns } \\
\left(\times 10^{3} \text { INRs ha }^{-1}\right)\end{array}$ & $\begin{array}{l}\mathrm{B}: \mathrm{C} \\
\text { ratio }\end{array}$ & $\begin{array}{c}\text { Cost of } \\
\text { cultivation } \\
\left(\times 10^{3} \text { INRs ha-1) }\right. \\
\end{array}$ & $\begin{array}{c}\text { Net returns } \\
\left(\times 10^{3} \text { INRs ha }^{-1}\right)\end{array}$ & B:C ratio \\
\hline \multicolumn{7}{|c|}{ After wheat } \\
\hline No residue & 21.89 & 13.71 & 0.63 & 28.67 & 12.29 & 0.43 \\
\hline Crop residue & 27.29 & 21.16 & 0.78 & 35.37 & 33.80 & 0.96 \\
\hline Leucaena twigs & 24.89 & 17.80 & 0.72 & 32.67 & 27.92 & 0.85 \\
\hline \multicolumn{7}{|c|}{ After chickpea } \\
\hline No residue & 20.99 & 20.26 & 0.97 & 27.93 & 10.04 & 0.36 \\
\hline Crop residue & 26.39 & 30.54 & 1.16 & 34.63 & 31.78 & 0.92 \\
\hline Leucaena twigs & 23.99 & 33.94 & 1.41 & 31.93 & 26.31 & 0.82 \\
\hline \multicolumn{7}{|c|}{ After mustard } \\
\hline No residue & 20.51 & 33.88 & 1.65 & 27.14 & 12.56 & 0.46 \\
\hline Crop residue & 25.91 & 49.67 & 1.92 & 33.84 & 28.28 & 0.84 \\
\hline Leucaena twigs & 23.51 & 44.35 & 1.89 & 31.14 & 23.30 & 0.75 \\
\hline LSD $(\mathrm{P}<0.05)$ & - & 5.17 & 0.048 & - & 2.97 & 0.029 \\
\hline
\end{tabular}

ๆ The interaction effect of winter season crops and residue management practices

\subsection{System economics}

System economics showed remarkable variations attributable to preceding crops and residue-management practices (Tables 9-11). The cost of cultivation for all systems was higher for crop residue application, followed by Leucaena twigs, and was higher after wheat followed by mustard and the least with chickpea. In 2010-11, gross and net returns and B : C ratio were higher for Leucaena twigs, followed by crop residue, irrespective of the preceding winter-season crops.

However, in 2011-12, these were higher for crop residue. Clusterbean-based system was superior in net returns and B : C ratio, followed by greengram-based systems, and were higher after mustard, followed by that after chickpea.

\section{Discussion}

Crop residues and Leucaena twigs recorded significantly higher pearlmillet-equivalent yield compared with no-residue. In 2010-11, the performance of crop under Leucaena twigs was better, but in 201112, Leucaena twigs and crop residues showed better response in clusterbean-mustard and clusterbean-wheat systems (Table 6-8). The system productivity was the lowest in no-residue and the highest under crop residue and Leucaena twigs during both years of experimentation in 2010-11 and 2011-12. This was attributable to enriched soil nutrient build-up through the addition of a considerable amount of residue, resulting in higher productivity. The yield under no- residue treatment was apparently low because of limited availability of nutrients supplied from the recommended dose of fertilizers, and deficit soil moisture under rainfed situation. Residue application presumably improved physico-chemical and biological environment of the soil through addition of organic matter, enhanced microbial activity and thus increased the system productivity, as suggested by Singh et al. (2005, 2008). These findings corroborate several studies in wheatbased cropping system (Reddy et al. 1981), clusterbeanmustard system (Saxena et al. 1997), clusterbean-wheat system (Singh et al. 1998), and greengram-wheat system (Singh et al. 2008). Legumes have contributory effect in fixing atmospheric N2, and clusterbean after chickpea helped further to add N2 to crops, which resulted in higher pearlmillet-equivalent yield in the system. The market price of mustard and chickpea was higher than of wheat, which was reflected in significant variation in pearlmillet-equivalent yield. Cereal crops in general are less energy providing crops and result in higher yields per unit area than the legumes and oilseed crops. Pearlmillet-equivalent yield was higher in 201011 than in 2011-12, and this was attributable to slightly lower yield of pearlmillet and wheat in 2011-12. The higher seed equivalent yield with chickpea was attributable to the higher price of chickpea. Productivity of rainfed crops in the semi-arid environments of northwestern India is low and highly variable, is primarily depends on the rainfall pattern and other weather variables, and less application of other farm inputs like chemical fertilizers because of their increased costs. The higher market prices of the produce during 2011 could 
not compensate for the low yields. The higher clusterbean-equivalent yield, net returns, benefit: cost ratio and sustainable yield index were also reported by Meena et al. (2008) and Pandit et al. (2010). Double cropping in the rainfed areas having average annual rainfall of about $700 \mathrm{~mm}$ is feasible if the rainfall is fairly-distributed and the late monsoon rains in September-end or October are utilized in sowing and early establishment of winter season crops. While there is no major problem in the cultivation of crops like pearlmillet, or greengram during the rainy season, it is essential to have minimum soil moisture in early October when the crops, such as chickpea, mustard, and wheat, are sown in early November. It is possible to enhance soil moisture conservation and also nutrient status through retention of crop residues (an important component of CA) and Leucaena twigs (Singh et al. 2005). Leucaena hedges are recommended for bund stabilization, fodder and much biomass in rainfed regions (Sharma and Behara 2009; Sharma et al. 2010; 2011). Zero-tillage, another important component of $\mathrm{CA}$, has immense potential to reduce the cost of cultivation, save time and thus ensure timely sowing, reduce soil erosion and conserve moisture (Erenstein and Laxmi 2008; Pittlekow et al. 2014). Thus, adoption of these CA-based technologies, coupled with precise use of inputs like water, nutrients and farm machinery, can help in enhancing the productivity and profitability of rainfed crops in the semi-arid environments.

\section{Conclusion}

Based on the two-year's study of nine doublecropping systems with residue mulching under rainfed conditions, we concluded that the system productivity in terms of total pearlmillet-equivalent yields of summer or rainy season crops can result in the highest yield under clusterbean with Leucaena twigs, followed by crop residue retention.

Similarly, significantly higher wheat-equivalent yield of winter crops can result under mustard with Leucaena twigs, followed by that with crop residue retention.

It has also concluded that clusterbean-mustard double-cropping system with Leucaena twigs can result in the highest productivity and profitability, followed by clusterbean-wheat or clusterbean-chickpea systems. It is recommend to apply Leucaena twigs as mulch after sowing to improve the productivity and profitability under zero-till conditions in the rainfed, semi-arid environments of north-western India.

Finally, it can be suggested that there is possibility to grow a short-duration crop in the later part of the rainy-season by conserving the residual soil moisture of the late monsoon rains, and also following dry-season crop by adopting the resource-conserving technologies.

\section{Acknowledgements}

The research paper is a part of a $\mathrm{PhD}$ thesis of the first author at the ICAR-Indian Agricultural Research Institute (IARI). The financial support received from the Indian Council of Cultural Relations (ICCR) in granting SAARC fellowship and the Institute of Agriculture and Animal Sciences (IAAS), Tribhuvan University, Rampur for the study leave are gratefully acknowledged.

\section{References}

Acharya, C.L., O.C. Kapur, and S.P. Dixit. 1998. Moisture conservation for rainfed wheat production with alternative mulches and conservation tillage in hills of north-west India. Soil and Tillage Research 46:153-163.

Amgain, L.P., A.R. Sharma, J. Timsina, and P. Wagle. 2019. Water, nutrient, and energy use efficiencies of no-till rainfed cropping systems with or without residue retention in a semi-arid dryland area. Global J. Agriculture and Allied Sciences. Nepalese Agricultural Professionals in America1 (1): 30-42.

Casida, L.E.J., D. A. Klein, and T. Santaro. 1964. Soil dehydrogenase activity. Soil Science 98: 371-376.

Dhyani, S. K., R. Newaj, and A.R. Sharma. 2009. Agroforestry: its relation with agronomy, challenges and opportunities. Indian Journal of Agronomy 54(3): 259-266.

Erenstein, O., and V. Laxmi. 2008. Zero tillage impacts in India's rice-wheat systems: a review. Soil Tillage Research, 100, 1-14.

Gill, M.S., and I.P.S. Ahlawat. 2006. Crop diversification - its role towards sustainability and profitability. Indian Journal of Fertilizers 2(9): 125138.

Gomez, K.A., and A.A. Gomez. 1984. Statistical Procedures for Agricultural Research. John Willley and Sons, NY.

Green, V.S., D.E. Ctott, and M. Diack. 2006. Assay of fluorescein diacetate hydrolytic activityoptimization of soil samples. Soil Biology and Biochemistry 38: 693-701.

Jones, R. B., J.W. Wendt, W.T. Bunderson, and O.A. Itimu. 1996. Leucaena-maize alley cropping in Malawi. Part I: Effects of N, P and leaf application on maize yields and soil properties. Agroforestry Systems 33 (3): 281-294.

Lal, M., D.S. Bhati, and A.K. Nag. 2004. Economics and production potential of different cropping sequence on farmers' field. Journal of EcoPhysiology 7(3/4): 143-145.

Lehria, S.K., S.V. Bali, and B. Singh. 2006. Effect of green leaf manure of subabul (Leucaena leucocephala Lam. De Wit.) on maize crop and its residual effect on wheat crop, pp. 316-319. In: Proceedings of the IUFROS-ISTS l-UHF International Conference on World Perspective on 
Short-rotation Forestry for Industrial and Rural Development. Eds. Verma, K.S., Khurana, D.K and Christersson, I. Nauni, Solan, India.

Meena, S. L., M. Shamsudheen, and D. Dayal. 2008. Productivity of clusterbean (Cyamopsis tetragonoloba) and sesame (Sesamum indicum) intercropping system under different row ratio and nutrient management in arid region. Indian Journal of Agricultural Sciences 79(11): 901-905.

Nunan, N., M.A. Morgan, and M. Herlihy. 1998. Ultraviolet absorbance $(280 \mathrm{~nm})$ of compounds released from soil during chloroform fumigation as an estimate of the microbial biomass. Soil Biology and Biochemistry 30(12): 1599-1603.

Pandit, M.C., R.P. Singh, and R. Kumar. 2010. Economic analysis of adoption of zero tillage technology in wheat cultivation in trans-gangetic plains of India. Indian Journal of Agricultural Sciences 80(12): 1092-1094.

Pittelkow, C.M., X. Liang, B.A. Linquist, K.J. . Groenigen, J. Lee, M.E. Lundy, N.V. Gestel, J. Six, R.T. Venterea, and C.V. Kessel. 2014. Productivity limits and potentials of the principles of conservation agriculture. Nature, http://dx.doi.org/10.1038/nature13809.

Prasad, C., and P.C. Bhatia. 2007. Farming system research and extension approaches. In: Suraj Bhan, Karale, R.L. Singh S., Bharati, K. and Subramaniyan, S. (Eds.), Conservation Farming, pp. 429-445. Soil Conservation Society of India, New Delhi.

Reddy, T.V., K.R. Reddy, M.S. Rajan, and G.S. Reddy. 1981. Production potential of seed clusterbean genotypes as sequence crop in dryland. Indian Journal of Agronomy 26: 89-90.

Saxena, A., D.V. Singh, and N.L. Joshi. 1997. Effects of tillage and cropping systems on soil moisture balance and pearlmillet yield. Journal Agronomy and Crop Science 178: 251-257.

Saxena, M.C. 2012. Challenges and opportunities for food legume research and development. Paper presented on the 6th M.S. Swaminathan Award Lecture at IARI, Pusa, New Delhi, January 25, 2012.

Sharma, A.R., and U.K. Behera. 2009. Nitrogen contribution through Sesbania green manure and dual-purpose legumes in maize-wheat cropping system: agronomic and economic considerations. Plant and Soil 325(1/2): 289-304.

Sharma, A.R., R. Singh, S.K. Dhyani, and R.K. Dube. 2010. Moisture conservation and nitrogen recycling through legume mulching in rainfed maize (Zea mays)-wheat (Triticum aestivum) cropping system. Nutrient Cycling in Agroecosystems, 87(2): 187197.

Sharma, A.R., R. Singh, S.K. Dhyani, and R.K. Dube. 2011. Agronomic and economic evaluation of mulching on rainfed-maize-wheat cropping system on the western himalayan region of India. Journal of Crop Improvement 25(4): 392-408.

Sharma, P.K., and C.L. Acharya. 2000. Carry-over of residual soil moisture with mulching and conservation tillage practices for sowing of rainfed wheat (Triticum aestivum) in north-west India. Soil and Tillage Research 57: 43-52.

Sidhu, H.S., M. Singh, E. Humphreys, YadvinderSingh, J. Blackwell, and S. Singh. 2007. The Happy Seeder enables direct drilling of wheat into rice stubble. Australian Journal of Experimental Agriculture 47: 844-854.

Singh, R., B. Singh, and M. Patidar. 2008. Effect of preceding crops and nutrient management on productivity of wheat (Triticum aestivum)-based cropping system in arid region. Indian Journal of Agronomy 53(4): 267-272.

Singh, V., S.K. Sharma, D. Ram, R.K. Siag, and B.L. Verma. 1998. Performance of different crops sequences under various irrigation levels. Indian Journal of Agronomy 35: 287-296.

Singh, Y., B. Singh, and J. Timsina. 2005. Crop residue management for nutrient cycling and improving soil productivity in rice-ba 